\title{
COMPARATIVE LEGAL ASPECTS OF ENSURING THE ECONOMIC SECURITY OF COMPANIES IN RESOLVING CORPORATE CONFLICTS IN UKRAINE AND THE UNITED STATES
}

\author{
Vitalii Demianchuk', Pavlo Bortsevych ${ }^{2}$
}

\begin{abstract}
The aim of the article is to reveal the legal nature of corporate conflicts and ways to overcome them in Ukraine and the United States. The subject of the study is corporate conflicts caused by the corporate relations that arise between the owners of corporate rights, as well as the relationship between the owners of corporate rights and management bodies of the company. Methodology. The study is based on general scientific and specialscientific methods and techniques of scientific knowledge. The logical semantic method enabled to determine the content of the concepts of "corporate conflict" and "greenmail". The comparative legal method enabled to compare the doctrinal approaches to this issue. The same method enabled to analyse US law regarding the subject matter. The normative dogmatic method enabled to interpret the content of legal regulations of domestic and foreign legislation that regulate the issue of corporate conflicts and ways to overcome them. The system-structural method enabled to analyse objective and subjective causes of corporate conflicts. Methods of analysis and synthesis enabled to distinguish features of corporate blackmail as the cause of corporate conflicts. The method of legal modelling enabled to develop proposals regarding greenmail prevention in Ukraine. Practical implications. Studies on the issue of greenmail in the US helped to develop recommendations for prevention of greenmail in Ukraine, as well as to identify issues requiring further consideration and research. Relevance/originality. The concepts of "corporate conflict" and "greenmail" are defined. The objective and subjective causes of the occurrence of corporate conflicts, the reasons for their occurrence, as well as the subjective component of the parties to the corporate conflict are analysed. The absence of the legal definition of the concept of greenmail and the effective mechanism of its prevention is stated, therefore, appropriate recommendations to prevent its occurrence are formulated.
\end{abstract}

Key words: corporate conflict, conflict of interest, objective causes, subjective causes, greenmail, corporate blackmail.

JEL Classification: G34, M14, 016

\section{Introduction}

The company's development and economic stability and security are predetermined by the rapport and constructive dialogue between the owners of the company's corporate rights. In many modern countries with a developed market economy, due to legislation, judicial practice, and corporate relations development, the principles of overcoming corporate conflicts with the least economic risk for companies themselves have been created. In this regard, the study of the legal aspects of the mechanism for overcoming corporate conflicts using the experience of the United States is relevant and crucial to regulate on its basis the corporate relations of companies in countries with developing economies, in particular, Ukraine. The emergence of a market economy in Ukraine has led to the emergence of a large number of business partnerships and the active development of corporate legal relations.
In Ukraine, the advent of a market economy has led to the occurrence of a large number of business partnerships and the active development of corporate legal relations. The formation of new social relations has caused corporate conflicts. In most cases, the main causes of such conflicts are the inadequacy of the legal mechanism for ensuring the rights of the corporate relation participants and the lack of proper legal culture in corporate management.

It should be noted that the elucidation of the legal nature of corporate conflicts and ways to overcome them have been and remain relevant among scholars. However, despite the relevance of the issue, the revelation of the legal nature of corporate conflicts in Ukraine remains inadequate.

The aim of the article is corporate conflicts caused by the corporate relations that arise between the owners of

\footnotetext{
Corresponding author:

${ }^{1}$ Academician Stepan Demianchuk International University of Economics and Humanities, Ukraine.

${ }^{2}$ National Academy of Internal Affairs of Ukraine, Ukraine.
} 
corporate rights, as well as the relationship between the owners of corporate rights and management bodies of the company.

\section{Presentation of the main material}

The researchers define the concept of corporate conflict differently, especially as regards the delineation of this concept with the notion of "conflict of interest."

According to A. Bobryshev and E. Bokhanov, a corporate conflict can be defined as disagreements (disputes) between shareholders (investors) and managers regarding shareholders' rights violation that leads or may result in lawsuits against the company, controlling shareholder or managers in decisions taken by them, early termination of powers of management bodies, substantial change of shareholders. H. Aleksieiev argues that the concept of "corporate conflict" must be distinguished from the concept of "conflict of interests" (Alekseev, Bobryshev, Bokhanova, 2002).

A. Zhornokui claims that, unlike a corporate conflict, the term "conflict of interest" does not mean a situation of a corporate conflict, but a situation that has a high probability of a corporate conflict (Zhornokui, 2007).

In addition, a conflict of interest is defined as a situation in which a managerial decision is chosen under contradictions between the good of the company and own interest of the manager.

Summarizing the views of the scientists, corporate conflicts can be defined as conflicts that arise between the participants in corporate relations, directly related to corporate interests and those that cause negative consequences for both the enterprise and its participants or pose a real threat to their occurrence.

The occurrence and development of corporate conflicts are due to four groups of factors and causes: objective, organizational and managerial, sociopsychological and personal. The first two groups are objective, the third and fourth are subjective (Danilova, 2010).

Understanding the objective and subjective nature of the causes of corporate conflicts in the management of a joint stock company is very useful for their prevention, for the development of optimal strategies for the shareholders' behaviour during typical conflicts. The objective causes for their occurrence are mainly the circumstances of the social interaction of shareholders, which have led to the collision of interests, thoughts, etc.

For example, the board of directors of a joint-stock company has a vacancy for a post of a board member, which is claimed by several persons from managerial personnel, who, in accordance with the current legislation, are in labour relations with the company. Since the vacancy is one and applicants are several, the interests of the latter coincide objectively, that is, regardless of their desire. Such a coincidence can lead to a conflict.
The subjective causes of corporate conflicts are related mainly to the individual psychological features of the opponents who choose the conflict, and not some other way of resolving the objective contradiction. In this case, the shareholder does not consider a compromise solution, does not try to discuss this contradiction together with the opponent to remove it, but chooses a strategy of counteraction. In our opinion, the reasons for which the shareholder chooses a conflict are subjective in the context of the above.

In our opinion, the reasons why a shareholder chooses a conflict in this context are subjective.

Even under superficial consideration of the nature of the relations between objective and subjective causes of conflicts, the specificities are evident, such as a clear distribution of objective and subjective causes of conflicts or their opposition, obviously, is unjustified. Any objective cause is important in the occurrence of a particular conflict situation, including due to the subjective factors.

It should be noted that approval of the regulations on the joint-stock company management by the general meeting of shareholders could contribute to reducing the number of corporate conflicts through the settlement of situations, which may cause corporate conflicts, in these documents.

However, in most cases, the elaboration of such instruments depends on the personal initiative of joint-stock company officials, that is, on the subjective factor. Therefore, the majority of objective causes are to a certain extent subjective, and the subjective motives of conflicts are ultimately objectively determined.

As a rule, the subject-matter of a corporate conflict in joint stock companies is the ownership of the shares of the company and rights that these securities give (participation in management, participation in the distribution of company profits, etc.). The interests of shareholders are aimed at revenue from the company's activities. Revenue can be realized in two ways: dividends and increase of exchange rate of shares (Moroz).

Studying the legal nature of corporate conflicts, the subjective composition of the parties to the corporate conflict should be considered.

The persons who may be participants in a corporate conflict can be grouped into:

- majority shareholders;

- minority shareholders;

- members of the Board of Directors (Supervisory Board) and managers.

Majority shareholders are focused on the long-term prospects of company development and minimal risks. If they have to choose between dividends and profits capitalization, they tend to prefer profits capitalization, as it contributes to the sustainability and strategic plans of the company's development.

The interests of minority shareholders differ. They are interested in short-term prospects, such as revenue from 
their participation in the company now. Therefore, the main interest of minority shareholders (dividends) will prevail over profits capitalization.

Meanwhile, company managers do not face the risk of losing their property. If a company becomes unprofitable, managers lose their jobs, but not their property. If such activity is profitable, managers receive a bonus. Managers risk not their property, but the property of owners (shareholders). Moreover, since managers are not owners, the risk of abuse on their part in relation to both the company and its owners exists. The conflict between managers and owners is the most frequently encountered corporate conflict (Iorhachova, 2011).

The study of the legal nature of the conflicts that arise in corporate relations reveals that one of the reasons for the occurrence of corporate conflicts is the abuse of corporate rights, in particular, greenmail, or in other words, corporate blackmail.

In the specialized literature, the term greenmail is interpreted as a procedure for acquiring a significant number of shares in a company to challenge it with the threat of hostile takeover with a view to further reselling these shares at a premium price for the targeted company (Bielikov, Hraivoronskyi, Kholchenkov, 2009).

For example, the greenmailer can offer shareholders or the joint-stock company itself to buy any batch of shares at "a bid price", that is, for a higher and unacceptable price. In case of failure, the greenmailer begins a war against this joint-stock company. Sometimes this is done through various manipulations with the right to convene a general meeting of shareholders. In particular, the joint-stock company is flooded with requirements for the election of the new board of a joint-stock company, fraudulent documents are used, numerous lawsuits are filed and continuous legal proceedings begin.

Actions for securing a claim and other proceedings in a court session may be used by greenmailers in their favour. In some cases, this is done in order to reduce its capitalization and make it more sensitive to hostile takeovers by striking the business reputation of an economic partnership. In other cases, greenmailers act for the main competitor of their chosen victim, for example, before a large tender for order distribution. Provided the value of the company's business is much smaller than its assets (buildings, land), the third possibility occurs.

In addition, greenmail also refers to individual cases of counteracting the reorganization of the company. It should be noted that other means of greenmailers' actions exist.

Evidently, the relationship between the joint-stock company and a greenmailer is the relationship between the company and its shareholder, within which the shareholder abuses his/her rights.

Thus, the following main features of corporate blackmail can be distinguished: 1) this is a form of interference in the activities of a joint-stock company;
2) based on the fact of possession of a certain number of shares, which does not allow having a significant impact on the management of a joint stock company; 3) the interference is aimed at hampering the operating activities of the joint-stock company and, consequently, creating certain negative consequences for the company and (or) its shareholders, including their finance and property; 4) the purpose of such actions is the sale of the block of shares at a premium price to the controlling shareholder or the company itself or to receive other property provision; 5) while the actions of corporate blackmailers are formally legal, they can be qualified as abusive rights (Gololobov, 2004).

In the United States, where corporate blackmail was used for the first time, different approaches to understanding and assessing greenmail exist both at the legislative level and in the legal science community. In 1984, US corporations spent over $\$ 3.5$ billion to reacquire securities from unwanted shareholders at premiums totalling over $\$ 600$ million above market prices (Williams, 1985).

The main factor that caused the growth of cases of companies' repurchases of their shares at a premium price was the tendency for corporate raiders to use market openness and the possibility of negotiated acquiring of shares for the accumulation of shares that enabled to circumvent more stringent requirements of the legislation on a tender offer (Hartnett).

In the US, at the federal level, no regulations ban greenmail.Moreover, greenmail is possible and regulated in detail by the current Federal Tax Laws of the United States. Thus, according to the Internal Revenue Code, the income, which is recognized as greenmail, is taxed at 50 percent (Greenmail).

Therefore, US legislators decided to "punish" greenmailers, imposing a tax burden on them, and making, in effect, corporate blackmail economically inappropriate for greenmailers. Meanwhile, it is also a good way to replenish the state treasury. However, in practice, this legislative measure fails to provide protection for the corporation itself, which has to pay huge premiums in case of a corporate takeover threat. It should be noted that only in a few states US state laws provide for restrictions on the purchase of shares above the market value in certain cases (Molotnikov, Garslian).

In New York, it is provided for that no domestic corporation shall purchase more than ten percent of the stock of the corporation for more than the market value thereof unless such purchase is approved by the affirmative vote of the board of directors and a majority of the votes of all outstanding shares at a meeting of shareholders. However, the prohibition shall not apply when the corporation offers to purchase shares from all holders of stock or for stock, which the holder has been the beneficial owner of for more than two years (New York Consolidated Laws). Similar provisions are in the 
states of Minnesota (Minnesota Statutes) and Arizona (Arizona Revised Statutes).

Therefore, even in the specified states, greenmail is not banned, only certain procedural restrictions are imposed. This can be explained by the fact that states cannot establish regulations in any way contrary to federal law. However, these restrictions still affect the state of affairs in corporate blackmail.

The main effect of these restrictions on greenmail is that companies become less appealing to raiders due to the elimination of one of the means of proceeds (Molotnikov, Garslian). Moreover, according to scientists, these provisions may restrict speculation in shares and prevent the decrease in the value of shares, which often follows the redemption of shares in such situations (Profusek, Bober, Johnson, 1986).

The analysis of the provisions of the Civil Code of Ukraine (Tsyvilnyi kodeks Ukrainy), as well as the provisions of the Law of Ukraine "On Joint Stock Companies" (Pro aktsionerni tovarystva), enables to state the absence of a legal definition of the concept of greenmail and effective mechanism for its prevention. This is because in Ukraine, the phenomenon of greenmail has not yet become widely used since corporate relations are developed insufficiently in comparison with the USA, however, the possibility of the significant distribution of greenmail in the future should not be excluded.

Therefore, it should be noted that the modern development of corporate relations is accompanied by the occurrence and existence of various corporate conflicts, which leads to the violation of the rights of participants of corporate relations.

It is worth agreeing that corporate conflict and conflict of interest are different concepts, although they are interconnected.

The basis of any corporate conflict is objective organizational, managerial, socio-psychological, and personal factors.

\section{Conclusion}

Summarizing the approaches of researchers to solving the problem of greenmail leads to the conclusion that in order to prevent the occurrence of greenmail, every legal entity in Ukraine should develop a set of protection that would include:

- minority shareholders minimization;

- compliance of the internal corporate documents of the company with the current legal regulations;

- maximum compliance with the rights of shareholders provided for by law;

- control over access to insider information of the company;

- prevention of corporate intelligence, third-party influence on management.

Considering that the mechanism of corporate rights protection in Ukrainian companies is in the process of formation, it would be advisable to use the positive experience of the US and American companies in combating this phenomenon to prevent greenmail.

\section{References:}

Alekseev, G. V., Bobryshev, A. D., Bokhanova, E. N. (2002). Korporativnye konflikty: prichiny ikh vozniknoveniia i sposoby preodoleniia [Corporate conflicts: causes of their occurrence and ways to overcome]. M.: Editorial. (in Russian)

Zhornokui, Yu. (2007). "Konflikt interesiv" ta "korporatyvnyi konflikt": spilni ta vidminni oznaky ["Conflict of interest" and "corporate conflict": Common and distinctive features]. Hospodarske pravo, 11, 45. (in Ukrainian)

Danilova, E. I. (2010). Doslidzhennia prychyn vynyknennia korporatyvnykh konfliktiv [Investigation of the causes of corporate conflicts]. Naukovi pratsi Natsionalnoho universytetu kharchovykh tekhnolohii, 35, 66-70. (in Ukrainian)

Moroz, O. V. Sotsialno-ekonomichnyi zmist korporatyvnoho konfliktu na suchasnomu pidpryiemstvi [Socioeconomic content of the corporate conflict at the modern enterprise]. Visnyk Vinnytskoho politekhnichnoho instytutu, 3, 22. (in Ukrainian)

Iorhachova, M. I. (2011). Korporatyvni konflikty v Ukraini: osnovni vydy ta ikh znachushchist [Corporate conflicts in Ukraine: main types and their significance]. Visnyk Natsionalnoho universytetu Lvivska politekhnika, $698,173$. (in Ukrainian)

Bielikov, O. O., Hraivoronskyi, A. V., Kholchenkov, O. M. (2009). Velykyi reiderskyi slovnyk [Great Raiders Dictionary]. K.: Publishing House Justinian. (in Ukrainian)

Gololobov, D. V. (2004). Aktsionernoe obshchestvo protiv aktsionera. Protivodeistvie korporativnomu shantazhu [Joint stock company against a shareholder. Opposition to corporate blackmail]. M.: Justicinform. (in Russian)

Williams, J. D. (1985, January 2). Companies' Stock Buybacks Soared in 1984 but Might Slow This Year. The Wall Street Journal, 6B, col. 1.

Hartnett, D. J. Comment: Greenmail: Can the Abuses Be Stopped? 80 Nw. U.L. Rev. 1271.

"Greenmail," Title 26 U.S. Code, Sec. 5881.

Molotnikov, A., Garslian, L. Ukroshchenie "stroptivykh": kvalifikatsiia i otvetstvennost za korporativnyi shantazh v Rossii i SShA [Taming the "obstinate": Qualification and responsibility for corporate blackmail in Russia and the United States]. Retrieved from: http://отрасли-права.рф/article/16095 (in Russian)

New York Consolidated Laws, Business Corporation Law, Sec. 513.

Minnesota Statutes. Ann. Sec. 302 A. 553, subd. (3). 
Arizona Revised Statutes. Ann. Sec. 10-1204.

Molotnikov, A., Garslian, L. Ukroshchenie "stroptivykh": kvalifikatsiia i otvetstvennost za korporativnyi shantazh v Rossii i SshA [Taming the "obstinate": Qualification and responsibility for corporate blackmail in Russia and the United States]. Retrieved from: http://отрасли-права.p $\phi /$ article/16095. (in Russian)

Profusek, R., Bober J., Johnson, D. (Fall, 1986). An Overview of Current Basic Takeover Planning Techniques. 14 Sec. Reg. L.J., 195, 219.

Tsyvilnyi kodeks Ukrainy (iz zminamy ta dopovnenniamy) [Civil Code of Ukraine (with amendments and supplements)] (2003). (Art. 356). Vidomosti Verkhovnoii Rady Ukrainy, 40-44. (in Ukrainian)

Pro aktsionerni tovarystva [On Joint-Stock Companies] Law of Ukraine no. 514-VI of September 17, 2008. Retrieved from: http://zakon4.rada.gov.ua/laws/show/514-17/page (in Ukrainian) 